\title{
North Carolina Library Networks: A Bibliography on Library Cooperation Involving the Old North State
}

\author{
compiled by Plummer Alston Jones, Jr.
}

Advances in telecommunications and the widespread use of microcomputers in libraries of all types and sizes have together revolutionized access to library resources and the delivery of library services. The most obvious effect of this technological revolution is that decentralized, electronic access to information has begun to supplant centralized, on-site maintenance of library materials.

Another, more personal, effect of this revolution is that library users, having been introduced to more sophisticated methods of obtaining information, now have great expectations of libraries and librarians to fulfill and even anticipate their information needs. Paradoxically, libraries are simultaneously experiencing financial hard times. How will libraries cope with the dilemma of great expectations during hard times?

The antidote to this Dickensian dilemma also has a literary allusion. As no man is an island, to paraphrase Donne, no library is self-sufficient. Since the late 1960 s, libraries have in ever increasing numbers realized that at least one solution to the dilemma is cooperation. Beginning with arguably the most successful cooperative venture in the library world to date, the Online Computer Library Center (OCLC), libraries have created other networks for the electronic exchange of information. This phenomenon of library networking to solve a multitude of dilemmas has been most prevalent and conspicuous in North Carolina beginning in the late 1970s and continuing into the 1990s.

The following bibliography on networks involving North Carolina libraries includes articles published since 1986 in no less than ten library periodicals reaching state, regional, and national audiences. For convenience, these articles have been classified according to the geographical areas and political arenas in which the networking activities described have had the greatest impact, for example, statewide networks, county networks, consortia crossing county boundaries, and regional consortia crossing state boundaries. Within each of these categories, citations to periodical articles are listed alphabetically by author. Citations to two or more articles by the same author are listed chronologically.

A lagniappe of this bibliography is that it serves as a preliminary or working directory of library networks throughout the Old North State, including, in addition to the statewide umbrella network, the North Carolina Information Network (NCIN), no less than thirty-seven academic libraries, six public libraries, twelve school libraries, and three special libraries. The challenge for these libraries is to keep the library community of North Carolina and the nation abreast of changes and developments in their respective networks. North Carolina libraries involved in networks which do not appear in this bibliography should publish or otherwise disseminate descriptions of their networking activities in order that the library community may benefit from the richness and variety of cooperative experiences involving the Old North State.

I. STATE:
A. North Carolina Information Network (NCIN)

Gilster, Paul. "New Network Connects Businesses with State." North Carolina Libraries 45 (Fall 1987): 148-49.

Gilster's article on the business-related information resources and services available through the North Carolina Information Network (NCIN) was reprinted with permission from the July 13-20, 1987 issue of Triangle Business. Gilster points out the State Library's decision "to be a contractor of services rather than a creator of them," and quotes then State Librarian Jane Williams, "The important thing [about the NCIN] is that we're contracting with OCLC and Western Union rather than putting millions into a mainframe here [in Raleigh] and a big staff and programming."

McClure, Charles R., Joe Ryan, Diana Lauterbach, and William E. Moen. "Site Visit: North Carolina Information Network (NCIN)." In Public Libraries and the INTERNET/NREN: New Challenges, New Opportunities, 9-18. Syracuse, NY: School of Information Studies, Syracuse University, 1992.

This recently published report on the role of public libraries in emerging and developing national networks includes a chapter based on a site visit to analyze and evaluate the NCIN. The NCIN was chosen because it is "a large-scale networking development effort that included a number of different types of libraries" and "an innovative leader in the application of networking services to public libraries." 
McGinn, Howard F. "The North Carolina Information Network-A Vital Cog in

Economic Development." North Carolina Libraries 44 (Fall 1986): 175-80.

In this article, the first in his series of articles on the NCIN, McGinn, in his capacity as Coordinator of Network Development for the State Library of North Carolina, calls for the establishment of a partnership between libraries and the business community. The NCIN will be at the heart of this cooperative enterprise. McGinn describes five ongoing projects of the NCIN: (1) North Carolina Online Union Catalog; (2) North Carolina Union List of Serials; (3) business, technical, and educational databases; (4) electronic mail/bulletin board service; and (5) document delivery services. In the development and nurture of the NCIN, the State Library is pledged (1) to work with other state agencies; (2) to work with statewide business organizations; (3) to conduct regional marketing surveys; (4) to develop business expert and consultation services; and (5) to coordinate planning.

. "Information Networking and Economic Development." Wilson Library Bulletin 62 (Nov. 1987): 28-32.

McGinn, in his capacity as Assistant State Librarian and Director of the North Carolina Information Network, uses this national periodical forum to promote the NCIN.

_. "Electronic Services for Rural Libraries: Meeting the Challenge in North Carolina." RQ 29 (Summer 1990): 492-96.

Focusing on the needs of rural libraries for timely access to information, McGinn, in his current position as State Librarian of North Carolina, urges participation in the NCIN for the benefits to be derived not only in terms of cost containment and cost sharing, but also in terms of the enhancement of the professional image of the local librarian. McGinn argues convincingly that "the library that prospers will be the one that carves out a place for itself in the vital daily operations of the rural community."

\section{_. "Information and the Development of Rural North Carolina." Southeastern Librarian 40 (Summer 1990): 75-79.}

State Librarian McGinn discusses the business- and consumer-oriented electronic bulletin board services available on NCIN, specifically, NCBTECH, from the North Carolina Biotechnology Center, NCDATA, from the State Data Center of North Carolina, and NCSTRC, from the North Carolina Department of Commerce's Science and Technology Research Center. Electronic bulletin boards associated with the Automated Purchase Directory present timely information on business contract opportunities with the State Government. Through online access to these services, McGinn asserts that "rural areas can now participate in the global economy."

Miller, Marilyn E. "Interlibrary Loan in the North Carolina Information Network: The Impact of "Selective Users" on a Net-Lender University Library." North Carolina Libraries 45 (Winter 1987): 210-15.

Miller presents a case study of East Carolina University's experience in filling interlibrary loan (ILL) requests from selective users of the North Carolina Online Union Catalog and the OCLC ILLS Subsystem via NCIN's dial access service. East Carolina University, the third largest university in the University of North Carolina system, is a net-lender.

"New State Library Network Starts Up in North Carolina." Library Journal 112 (1 Feb. 1987): 24 .

This brief news release describing what will later be called the NCIN is perhaps the first official announcement to reach a national and international audience. The release announces that the North Carolina network "combines highly centralized data management with highly decentralized access."

Young, Diana. "North Carolina's Information Network and Youth Services." Public Libraries 27 (Spring 1988): 39-40.

—. "North Carolina Information Network." Tar Heel Libraries 14 (May/June 1991): 3-4. Young's articles provide a description of several components of the NCIN, including (1) the North Carolina Online Union Catalog and the OCLC ILL subsystem; (2) North Carolina Union List of Serials; (3) electronic mail, (4) electronic bulletin board, (5) access to databases, and (6) information delivery by telefacsimile and courier. The former, more expansive article is geared to librarians serving children and young adults; the latter, a brief reference list for the general library community.

\section{B. Other Statewide Efforts}

Lithgo, Sue Wanchock. "Public Libraries/Agricultural Extension Agencies: Potential for Cooperation." Rural Libraries 7 (1) (1987): 7-42.

Lithgo's study encourages ongoing cooperation between public libraries, with coordination 
provided by the State Library of North Carolina, and county agricultural extension agencies, with coordination provided by the North Carolina Agricultural Extension Service. Cooperative planning would benefit North Carolina citizens needing agricultural information and services.

"MUGLNC [Microcomputer Users Group for Libraries in North Carolina]." Tar Heel Libraries 15 (May/June 1992): 14.

Celebrating the tenth anniversary of its founding in 1982, MUGLNC is a non-profit organization dedicated to basic computer education. With the explosion of computer networks throughout North Carolina, the nation, and the world, MUGLNC will begin to explore ways for libraries to collaborate and cooperate in the hi-tech environment of the 1990s.

Welch, Jeanie M., and Lorraine W. Penninger. "Hanging Together: Local Cooperation and Role Expectations Among Different Types of North Carolina Libraries." North Carolina Libraries 46 (Winter 1988): 237-44.

Welch and Penninger surveyed 126 libraries of different types throughout North Carolina to determine the amount and types of local cooperation and role expectations. Of the ninety-two responses received, thirty-five were from academic libraries; seventeen from public libraries; twenty-six from secondary school libraries; and fourteen from special libraries. The responses showed that North Carolina libraries are cooperating, particularly academic and public libraries with the encouragement of the State Library of North Carolina, and that libraries of all types for social and economic reasons are open to creative means of cooperation.

\section{COUNTY}

Bileckyj, Peter A. "The Wilson County Networking Project." North Carolina Libraries 44 (Fall 1986): 146-54.

The Wilson County Libraries Networking Project grew out of a ZOC (Zone of Cooperation) grant awarded in 1984 by the Steering Committee of the State Library of North Carolina's Networking Committee. Institutional members of the network are Wilson County Public Library, Wilson County Technical College, Barton College, Wilson Memorial Hospital, Eastern North Carolina School for the Deaf, Beddingfield High School, Fike High School, and Hunt High School. The network has two purposes: (1) to exchange information via an electronic bulletin board system; and (2) to build bibliographical products, including union lists of periodicals and audiovisuals.

Jones, John. "Electronic Network Project." Tar Heel Libraries 14 (May/June 1991): 5. Using Library Services and Construction Act (LSCA) Title III funds, the Neuse Regional Library implemented the Electronic Network Project in the fall of 1990. The Electronic Network Project links the reference department of the Neuse Regional Library, a public library, to three high school libraries in Lenoir County, Kinston High School, North Lenoir High School, and South Lenoir High School. The project exposes high school students to telefacsimile and CD-ROM technologies. The administrations of the high schools involved have agreed to assume costs for continuing the project. A private high school in Lenoir County and a public high school in neighboring Green County have recently joined the network.

Kester, Diane D. "Access to Information-Can Schools Provide It?" North Carolina Libraries 44 (Fall 1986): 135-38.

Kester presents a review of the literature on school library cooperation with discussions of local and state networks involving school libraries in New York City, New York State, Alaska, New Jersey, Connecticut, and Colorado. School library participation in OCLC at the national level and in various state and regional cooperative networks is noted, including SOLINET (southeastern states), ILLINET (Illinois), INCOLSA (Indiana), OHIONET (Ohio), PACNET (six systems in the Pacific Network of OCLC), and MILO (Montgomery County, Maryland). Discussions of the Cleve-net project and the Wilson County Libraries Network project, two North Carolina networks involving school libraries, round out the review.

Perry, Douglas. "The Cleve-net Library Project: An Electronic Mail and Shared Data Network." North Carolina Libraries 44 (Fall 1986): 140-44.

Created with funds received from a 1984 ZOC grant from theSteering Committee of the State Library of North Carolina's Networking Committee, Cleve-net is an online electronic mail and shared data network serving the multi-type libraries of the Broad River Library/Media Association, located in Cleveland County and neighboring counties. Institutional participants in Cleve-net, since it became operational in September 1985, are Cleveland County Memorial Library, Cleveland County Technical College, Gardner-Webb College, Mauney Memorial Library, Burns High School, Crest high School, Kings Mountain High School, and Shelby High School.

Ritter, Phil. "The Information Network." Tar Heel Libraries 14 (May/June 1991): 3. The Gaston County Public Library (GCPL) has established the "Information Network," 
which provides county businesses with access to current information in print and electronic formats. The GCPL also taps the information resources available through the NCIN and from the Gaston County Chamber of Commerce, Gaston College, and local business firms.

Sermons, Penny G. "DEAN: Down East Area Network." Tar Heel Libraries 14 (May/June 1991): $4-5$.

_ "Beaufort County Community College Library Establishes Down East Area Network." North Carolina Libraries 49 (Summer 1991): 85.

In January 1991, the Beaufort County Community College Library (BCCCL) implemented the first phase of the Down East Area Network (DEAN) to provide access to its resources and services from two Beaufort County public high schools, Aurora High School and Northside High School, and the Beaufort-Hyde-Martin (BHM) Regional Public Library. During phase two, the BCCCL plans to include other public and school libraries in its four-county service area in eastern North Carolina.

Shannon, Donna. "Cooperation Between School and Public Libraries: A Study of One North Carolina County." North Carolina Libraries 49 (Summer 1991): 67-70.

The purpose of Shannon's study was to determine the nature and extent of cooperation among school and public library programs in an unidentified county with seventeen middle school libraries, thirteen high school libraries, and seventeen public libraries. Shannon confirmed the assumption that school libraries are unable to meet all the information needs of their students. As a corollary, it was important to know exactly when and for what kinds of information students turn to public libraries. Shannon asserts that commitment and communication are two essentials in developing and sustaining cooperative relationships among school and public libraries.

\section{CONSORTIA}

A. Mid-Carolina Academic Library Network (Mid-CAL)

\section{B. Mountain College Library Network (MCLN)}

Smith, Marti. "Mid-CAL: The Mid-Carolina Academic Library Network." Tar Heel Libraries 15 (Mar./Apr. 1992): 2-3.

The Mid-Carolina Academic Library Network (Mid- CAL) was formed in 1987 to promote library automation and networking among eleven institutions of which ten are still active participants. These ten institutions are Barton College, Campbell University, Louisburg College, Meredith College, Methodist College, North Carolina Wesleyan College, Peace College, Saint Mary's College, Shaw University, and St. Andrews Presbyterian College. In October 1990, Mid-CAL received a United States Department of Education (USDE) Title II Combination Grant of $\$ 164,000$ to be used to connect the libraries of the participating institutions with the Local and Intercampus North Carolina Network (LincNet) installed by the University of North Carolina Educational Computing Service (UNCECS).

Hutton, Jean. "Mountain College Library Network." Tar Heel Libraries 15 (Mar./Apr. 1992): 2. The original member libraries of the Mountain College Library Network (MCLN), established in 1990, were Montreat Anderson College, Mars Hill College, Asheville-Buncombe Technical Community College, and Warren Wilson College. Since then six libraries have joined the MCLN: Brevard College, Lees-McRae College, McDowell Technical Community College, Blue Ridge Technical Community College, Lenoir Rhyne College, and the Mountain Area Health Education Center. The MCLN participants share information from periodicals via a telefacsimile service and extend borrowing privileges on site to individuals from any of the participating institutions. Future plans include cooperative collection development and automated circulation of materials.

Jones, Plummer Alston, Jr. "Piedmont Independent College Association." Tar Heel Libraries 15 (Mar./Apr. 1992): 2.

The Piedmont Independent College Association (PICA) consortium includes the following six private colleges: Bennett College, Elon College, Greensboro College, Guilford College, High Point University, and Salem College. Using a 1989/90 USDE Title III-A grant of 2.5 million dollars over a five-year period, the PICA libraries will create an online union catalog and automated circulation systems. The central processing unit (CPU) for the network is located at Guilford College. The union catalog will be accessible not only to consortium members, but also to all North Carolina libraries via the LincNet installed and maintained by the UNCECS.

Owen, Willy. "The Triangle Research Libraries Network: A History and Philosophy." North Carolina Libraries 47 (Spring 1989): 43-51.

The Triangle Research Libraries Network (TRLN) was created by a consortium of three research

\section{Triangle Research Libraries Network (TRLN)}


universities in the Research Triangle Park area of North Carolina. The TRLN consortium is unusual in that it is comprised of two public universities, the University of North Carolina at Chapel Hill and North Carolina State University, and one private university, Duke University. Owen's article gives not only an in-depth retrospective review of the long history of cooperation among these universities from as early as 1933, but also an introspective look at the day-to-day problems faced by the consortium that resulted from this cooperation. The purpose of TRLN is the creation, development, and maintenance of a computerized network which provides online access to the library collections of three major research universities.

Ulmschneider, John, and Patrick Mullin. "Performance Measures for Online Systems." North Carolina Libraries 48 (Fall 1990): 197-204.

Ulmschneider and Mullin discuss how to evaluate the system performance of an online library system using three parameters: response time, application efficiency, and capacity. Their article concludes with a case study involving performances measures applied and results obtained at the TRLN.

\section{E. Western North Carolina Library Network (WNCLN)}

\section{REGIONAL AND INTRASTATE}

\section{A. North Carolina/Nebraska Information Partnership}

\author{
Dean, Nita. "Nebraska and North Carolina Become Information Partners." OCLC \\ Newsletter no. 194 (Nov./Dec. 1991): 14. \\ "NE and NC State Libraries Team Up; Sharing People and Resources to Support State \\ Economic Development." Library Journal 116 (Dec. 1991): 28+.
}

These brief news releases announce that in October 1991, Nebraska and North Carolina joined in a partnership to improve library and information services in the two states. Electronic exchange of information via the INTERNET will be the most immediate benefit of cooperation. Staff exchange programs involving Nebraska and North Carolina librarians are being discussed. Economic development in both states will be enhanced in the long term.

Grisham, Frank P. "The Role of the Regional Network in Assisting the Development of Local Networks." Southeastern Librarian 38 (Summer 1988): 57-58.

Grisham, Executive Director of SOLINET, discusses principles in library cooperation, networking among academic libraries, and the role of SOLINET to promote and facilitate internetwork cooperation among emerging local networks. He alludes specifically to the successes of NCIN and TRLN in North Carolina.

McGinn, Howard F. "Information, Economic Development, and Competitiveness in Southeastern United States." Southeastern Librarian 38 (Fall 1988): 96-100.

McGinn's article is based on his address to the Georgia Library Association at its biennial conference in October 1987. He reports on the progress of North Carolina and other southern states to transform their economies from manufacturing-based to service-and-informationbased. Using the NCIN as an example of how libraries can help in this transformational process, McGinn urges librarians to apply networking to the solution of community problems as well as library problems. The library will thus be at the heart of the information infrastructure. Along with airports, highways, water and sewer systems, libraries will then be seen "as prime candidates for the investment of scarce public funds."

"North Carolina and SOLINET." Tarheel Libraries 14 (May/June 1991): 5. As of June 1991, North Carolina had eighty-one members of SOLINET and 247 Selective Users with Group Access Capability (GAC). North Carolina libraries of all types cataloged a total of 506,412 items during fiscal year $1989 / 90$, loaned 108,381 items, with 56.7 percent going to other North Carolina libraries, and borrowed 92,209 items, with 69 percent coming from other North Carolina libraries. 